Article

\title{
Spatial Distribution and Land Use of Traditional Villages in Southwest China
}

\author{
Xiye Zheng ${ }^{1,2}$, Jiahui $\mathrm{Wu}^{1,2}$ and Hongbing Deng ${ }^{1, *}$ \\ 1 State Key Laboratory of Urban and Regional Ecology, Research Center for Eco-Environmental Sciences, \\ Chinese Academy of Sciences, Beijing 100085, China; xhzheng_st@rcees.ac.cn (X.Z.); \\ jhwu_st@rcees.ac.cn (J.W.) \\ 2 University of Chinese Academy of Sciences, Beijing 100049, China \\ * Correspondence: denghb@rcees.ac.cn
}

Citation: Zheng, X.; Wu, J.; Deng, H. Spatial Distribution and Land Use of Traditional Villages in Southwest China. Sustainability 2021, 13, 6326. https://doi.org/10.3390/su13116326

Academic Editors: Christopher Robin Bryant and Asterios Bakolas

Received: 18 April 2021

Accepted: 28 May 2021

Published: 2 June 2021

Publisher's Note: MDPI stays neutral with regard to jurisdictional claims in published maps and institutional affiliations.

Copyright: (c) 2021 by the authors. Licensee MDPI, Basel, Switzerland. This article is an open access article distributed under the terms and conditions of the Creative Commons Attribution (CC BY) license (https:// creativecommons.org/licenses/by/ $4.0 /)$.

\begin{abstract}
Traditional villages are the historical and cultural heritage of people around the world. With the increases in urbanization and industrialization, the continuation of traditional villages and the inheritance of historical and cultural heritage are facing risk. Therefore, to grasp the spatial characteristics of them and the human-nature interaction mechanism in Southwest China, we analyzed the distribution pattern of traditional villages using the ArcGIS software. Then, we further analyzed the spatial clustering characteristics, influencing factors and landscape pattern, and put forward relevant protection countermeasures and suggestions. The results revealed that traditional villages in Southwest China were clustered, being mainly distributed in areas with relatively low elevation, gentle slopes, low relative positions, nearby water sources, and convenient transportation. They can be divided into four categories due to obvious differences in influencing factors such as elevation, slope, relative position, distance to the nearest river, population density, etc. The landscape pattern of traditional villages differed among the different clusters, being mainly composed of forests, shrubs, and cultivated land. With the increase in the buffer radius, the landscape pattern of them changed significantly. The results of this study reflect that traditional villages and the natural environment are interdependent, so the protection of traditional villages should carry out measures according to local conditions.
\end{abstract}

Keywords: traditional villages; spatial distribution; influencing factors; landscape pattern; Southwest China

\section{Introduction}

Traditional villages, also termed ancient villages, refer to those with both material and intangible cultural heritage [1]. They have important historical, cultural, scientific, artistic, social, and economic value [2]. However, with the rapid urbanization and industrialization rate in China, reaching $60.60 \%$ and $39.56 \%$ in 2019 , respectively, villages are experiencing population outflow and ecological destruction [3-5], which are posing considerable obstacles to the protection and development of these villages. Because of its vast territory and long history, China has numerous traditional villages which are the most characteristic part of natural villages. However, from 2010 to 2018, the number of natural villages in China decreased by $10.2 \%$, and the rural permanent population decreased by $6.7 \%$ [6], which has led to the gradual disappearance of some traditional villages. Therefore, scientifically establishing protection mechanisms and maintaining the sustainable development of them have become the current concerns of both managers and researchers $[7,8]$.

Early research focused on the spatial characteristics and cultural value of individual traditional villages $[9,10]$. Some studies explored the protection mechanisms and sustainable development modes of them by studying the production and lifestyle, architectural, cultural, and natural landscapes of the villages [10-13], but these studies paid more attention to qualitative description and analysis. With the development of geographic 
information system (GIS), research on the spatial distribution characteristics of traditional villages from the regional scale has gained more attention [14-16]. However, there is still a lack of research on spatial quantitative analysis that combines the influencing factors and landscape patterns of traditional villages $[17,18]$.

The landscape pattern is influenced by both human activities and the natural environment [19]. In the processes of village formation and development, villagers' production activities affect the surrounding land use, and the social environment and policies significantly change the landscape pattern of villages [20,21]. The spatial distribution of traditional villages reflects the livability of traditional villages [16,22], whereas the landscape pattern reflects the human-land relationship formed over a long period [17]. Due to spatial heterogeneity, the distribution of landscape patterns is different in different regions [23]. Especially on a large scale, the distribution patterns are greatly affected by geographical conditions. Therefore, accurately measuring landscape patterns by combining geographical characteristics is conducive to better understanding the interactions between human activities and the natural environment around traditional villages [24]. At present, relevant departments in China have published five batches of traditional village lists, covering a total of 6819 villages, laying a foundation for the in-depth study [25]. However, under the comprehensive influence of the natural environment, social economy, historical culture, and other factors, the spatial distribution and landscape patterns of traditional villages are significantly different across the country [14-16,22,26]. Therefore, it is crucial to study the landscape pattern of traditional villages to protect the health of regional ecosystems and maintain the sustainable development of these villages [27].

Southwest China has complex and diverse topography and is rich in biological and cultural diversity $[28,29]$. This region is also one of the main Chinese traditional village gathering areas [25]. Therefore, to grasp the spatial characteristics of traditional villages and the human-nature interaction mechanism around traditional villages, taking Southwest China as the study area, we analyzed the spatial distribution pattern of traditional villages using the ArcGIS software. Then, we further analyzed the spatial clustering characteristics, influencing factors, and landscape patterns of traditional villages, and put forward relevant protection countermeasures and suggestions. The research results can provide a reference for the protection and sustainable development of traditional villages.

\section{Materials and Methods}

\subsection{Study Area}

The study area is located in Southwest China, which includes Sichuan Province, Chongqing city, Guizhou Province, Yunnan Province, and the Guangxi Zhuang Autonomous Region. The geographical location is $97^{\circ} 21^{\prime}-112^{\circ} 3^{\prime}$ E, $20^{\circ} 53^{\prime}-34^{\circ} 18^{\prime} \mathrm{N}$ (Figure 1a), and the land area is $1.36 \times 10^{6} \mathrm{~km}^{2}$. The topography in this area is complex, including the Sichuan Basin, Yunnan-Guizhou Plateau, Guangxi Hills, and Hengduan Mountains. The elevation differs widely, with an average elevation of $1700 \mathrm{~m}$. The study area has abundant natural resources, multitudinous river systems, and diverse types of ecosystems, being one of the biodiversity hotspots in China [28].

Southwest China is a gathering area of ethnic minorities, with 34 major ethnic minorities, forming a rich cultural diversity [29]. The ancient national architecture, rich traditional culture, and unique natural conditions additionally provide the foundation for the formation of traditional villages. As of 2019, 2155 villages in Southwest China were included in the list of Chinese traditional villages, accounting for $31.6 \%$ of the total. Among them, Guizhou Province and Yunnan Province were ranked the first and second provinces in China in terms of the number of traditional villages, with 724 and 708 villages, respectively. 

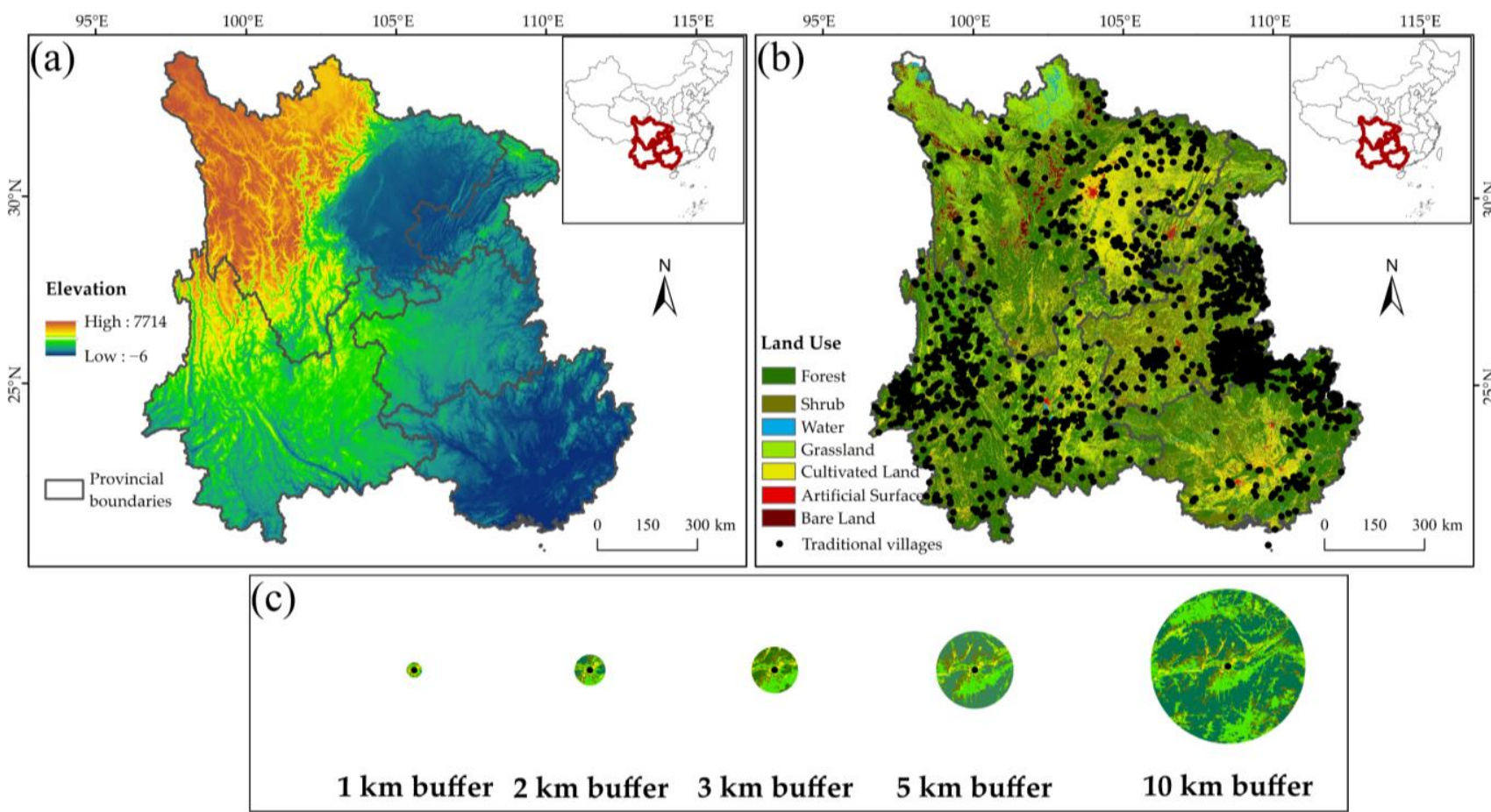

Figure 1. Map of Southwest China: (a) topographic map, (b) distribution of land use and traditional village map, and (c) study area with five different buffers of traditional village landscape patterns.

\subsection{Data Sources}

The data sources of this study included five main categories: (1) the list of traditional villages from the official website of the Ministry of Housing and Urban-Rural Development of China [30-34]; the spatial coordinates were calibrated using the Baidu vector query tool [35]; (2) administrative boundary vector data, water system vector data, and the digital elevation model $(30 \times 30 \mathrm{~m})$ were downloaded from Institute of Remote Sensing and Digital Earth, Chinese Academy of Sciences [36]; (3) land use data were obtained from the Chinese Academy of Sciences Resource and Environment Data Cloud Platform [37]; (4) the population density map was obtained from the Urban Data Party [38]; and (5) social and economic data were sourced from statistical yearbooks [39-43].

\subsection{Methods}

\subsubsection{Spatial Pattern Analysis}

The average nearest neighbor ratio $(R)$ and kernel density estimation (KDE) were often used to analyze the spatial distribution characteristics of spatial elements such as villages, settlements, and so on $[22,26]$. Therefore, this study used $R$ and KDE to analyze the spatial distribution pattern of traditional villages in Southwest China. $R$ is the ratio of the average distance from each point to the nearest point to the complete spatial randomness (CSR) pattern, which helps to identify the distribution types of traditional villages [26]. If $R$ approaches 0 , the villages are clustered; if $R$ approaches 1, the villages are discrete; if $R>0$, the villages are uniformly distributed; and if $R=1$, the villages are random $[26,44]$. The $R$ index was calculated using Equations (1) and (2):

$$
\begin{gathered}
\overline{r_{E}}=\frac{1}{2 \sqrt{n / A}}=\frac{1}{2 \sqrt{D}}, \\
R=\frac{\overline{r_{i}}}{\overline{r_{E}}}=2 \sqrt{D} \overline{r_{i}},
\end{gathered}
$$

where $n$ is the number of points, $A$ is the regional area, and $D$ is the density of the points. 
KDE is a nonparametric method used for estimating the probability density function of random variables. The general definition is: supposing $x_{1}, x_{2}, \ldots, x_{n}$ are independent, and extracting the same distribution samples from the distribution density function $f$, estimate the value of $f$ at a certain point $(x, y)[22,45]$. KDE is calculated by Equation (3):

$$
f(x, y)=\frac{1}{n h^{2}} \sum_{i=1}^{n} K\left(\frac{d_{i}}{h}\right),
$$

where $f(x, y)$ is the estimated density at location $(x, y), n$ is the number of traditional villages, $h$ is the bandwidth or kernel size, $K$ is the kernel function (i.e., the sizes of the land areas), and $d_{i}$ is the distance between the location $(x, y)$ and traditional villages.

\subsubsection{Analysis of Geographical Characteristics}

Using ArcGIS 10.5 (Environmental Systems Research Institute, Redlands, CA, USA), we analyzed and calculated five geographical features of traditional villages in Southwest China including elevation, slope, relative position, the distance to the nearest river, and traffic cost. They represent the three most important basic attributes of spatial elements and the indispensable conditions for residents' production and life. We extracted the elevation and slope from the digital elevation model. The distance to the nearest river was considered as the shortest straight distance from the traditional village to the nearest river. The relative position is the elevation position of the traditional village in the surrounding environment (Equation (4)). The traffic cost $\left(M_{i}\right)$ is the comprehensive minimum cost distance from traditional villages to provincial, city, county, and township centers and railway stations, which is calculated by using the minimum cumulative resistance (MCR) model. The MCR model is shown in Equations (5) and (6) [22,46,47]:

$$
\Delta H=\frac{H-H_{\min }}{H_{\max }-H_{\min }} \times 100 \%,
$$

where $H$ is the village elevation, $H_{\min }$ is the minimum elevation around the village, and $H_{\max }$ is the maximum elevation around the village. Considering the topography of Southwest China, the maximum and minimum elevations were extracted from the square areas with the village as the center and the side lengths of 5000, 10,000, and 20,000 $\mathrm{m}$ when the elevation of the village was less than 500,500-2000, and higher than $2000 \mathrm{~m}$, respectively:

$$
\begin{gathered}
M_{i j}=f_{\min } \sum\left(D_{i j} \times R_{j}\right), \\
M_{i}=\frac{1}{5} \sum_{j}^{n} M_{i j},
\end{gathered}
$$

where $M_{i j}$ is the minimum cumulative resistance value from source $j$ to landscape unit $i$, and the dispersion is standardized; $D_{i j}$ is the spatial distance from source $j$ to landscape unit $i ; R_{j}$ is the resistance coefficient, and the resistance value of each resistance is set up according to the relevant literature [22] and expert advice, combining special geographical environment of Southwest China (Table 1); $M_{i}$ is the composite MCR value of the traffic of each village; and $n$ includes the MCR values whose sources are the provinces, cities, counties, townships, and railway stations. 
Table 1. The value of each resistance.

\begin{tabular}{|c|c|c|c|}
\hline Factor & Name & Cost & Weight \\
\hline \multirow{7}{*}{ Types of road } & Highway & 1 & \multirow{7}{*}{0.6} \\
\hline & National highway & 2 & \\
\hline & Provincial highway & 3 & \\
\hline & County highway & 4 & \\
\hline & Village road & 5 & \\
\hline & Other road & 8 & \\
\hline & None & 30 & \\
\hline \multirow{4}{*}{ Land use type } & Grassland, cultivated land, artificial surface & 1 & \multirow{4}{*}{0.2} \\
\hline & Forest, shrubs & 2 & \\
\hline & Water & 3 & \\
\hline & Bare land & 4 & \\
\hline \multirow{4}{*}{ Slope $\left(^{\circ}\right)$} & $0-3$ & 1 & \multirow{4}{*}{0.2} \\
\hline & $3-15$ & 2 & \\
\hline & $15-25$ & 3 & \\
\hline & $25-90$ & 4 & \\
\hline
\end{tabular}

\subsubsection{Cluster Analysis}

Ward clustering is one of the mature hierarchical clustering methods. It emphasizes that the internal differences of similar things should be small, while the differences between different kinds should be large $[48,49]$. Therefore, this research first uses the regional statistical tools in ArcGIS software to calculate and extract the different spatial elements of each traditional village, including elevation, slope, relative position, distance to the nearest river, and transportation cost, and then uses the Ward method in SPSS statistics 26.0 analyze the clustering characteristics of traditional villages in Southwest China.

\subsubsection{Analysis of Land Use and Landscape Pattern}

The landscape pattern index is a quantitative index reflecting the structure and distribution of landscape patterns, which mainly includes the patch, class, and landscape levels. Since it would have been extremely difficult to obtain the area and shape of all traditional villages in the study area, the traditional villages were simplified as coordinate points in this study. According to the characteristics of human activities in traditional villages, we used traditional villages as the research center and established circular buffer zones of 1, 2, 3, 5, and $10 \mathrm{~km}$ (Figure 1b,c). The landscape pattern metrics in buffer zones with different radii were calculated using the FRAGSTATS V4.2 program. Considering the high correlation and redundancy among the indexes $[18,50]$, four representative indexes were selected to quantitatively analyze the landscape pattern characteristics (Table 2).

Table 2. Ecological significance and calculation formulas of landscape pattern metrics.

\begin{tabular}{|c|c|c|c|c|}
\hline Metric & Level & Formula & Annotate & Description \\
\hline $\begin{array}{l}\text { Area ratio } \\
(P L A N D)\end{array}$ & Class & $P L A N D=\frac{1}{T A} \sum_{j=1}^{N_{i}} A_{i j}$ & $\begin{array}{l}T A \text { is the total patch area of all } \\
\text { landscape elements; } A_{i j} \text { is the area of } \\
\text { patch } j \text { in the } i \text { th landscape }\end{array}$ & $\begin{array}{l}\text { Reflects the composition of } \\
\text { landscape components }\end{array}$ \\
\hline $\begin{array}{c}\text { Mean plaque area } \\
(M P S)\end{array}$ & & $M P S=\frac{1}{N_{i}} \sum_{j=1}^{N_{i}} A_{i j}$ & $\begin{array}{l}N_{i} \text { is the total number of patches of the } \\
i \text { th landscape element; } A_{i j} \text { is the area of } \\
\text { the } j \text { th patch in the } i \text { th landscape }\end{array}$ & Reflects the landscape scale \\
\hline $\begin{array}{l}\text { Patch } \\
\text { density } \\
(P D)\end{array}$ & Landscape & $P D=\frac{N_{i}}{T A}$ & $\begin{array}{l}N_{i} \text { is the total number of landscape } \\
\text { feature patches of type } i \text {; TA is the total } \\
\text { area of all landscape feature patches }\end{array}$ & $\begin{array}{l}\text { Reflects the degree of } \\
\text { landscape fragmentation: the } \\
\text { greater the patch density, the } \\
\text { greater the degree of } \\
\text { landscape fragmentation }\end{array}$ \\
\hline $\begin{array}{l}\text { Shannon } \\
\text { Diversity Index } \\
(S H D I)\end{array}$ & & $S H D I=-\sum_{i=1}^{m}\left(P_{i} \times \ln P_{i}\right)$ & $\begin{array}{c}P_{i} \text { is based on the total landscape area } \\
\text { excluding any internal background } \\
\text { present }\end{array}$ & Measures landscape diversity \\
\hline
\end{tabular}




\section{Results}

\subsection{Spatial Distribution Pattern and Geographical Features of Traditional Villages}

The $R$ index of traditional villages in Southwest China was $0.62(p<0.01)$, which indicated that the distribution of traditional villages in Southwest China was significantly clustered. The KDE analysis (Figure 2) showed that the density distribution of traditional villages in Southwest China had significant regional differences, with four high-density regions: Southeast Guizhou, Northeast Guangxi, and Central and Northwest Yunnan; the density in Sichuan, Chongqing, and Southwest Guangxi was generally low. The four cities with higher density in Southwest China were Qiandongnan Miao and the Dong Autonomous Prefecture (0.0119), Baoshan city (0.0051), Tongren city (0.0047), and Guilin city $(0.0040)$.

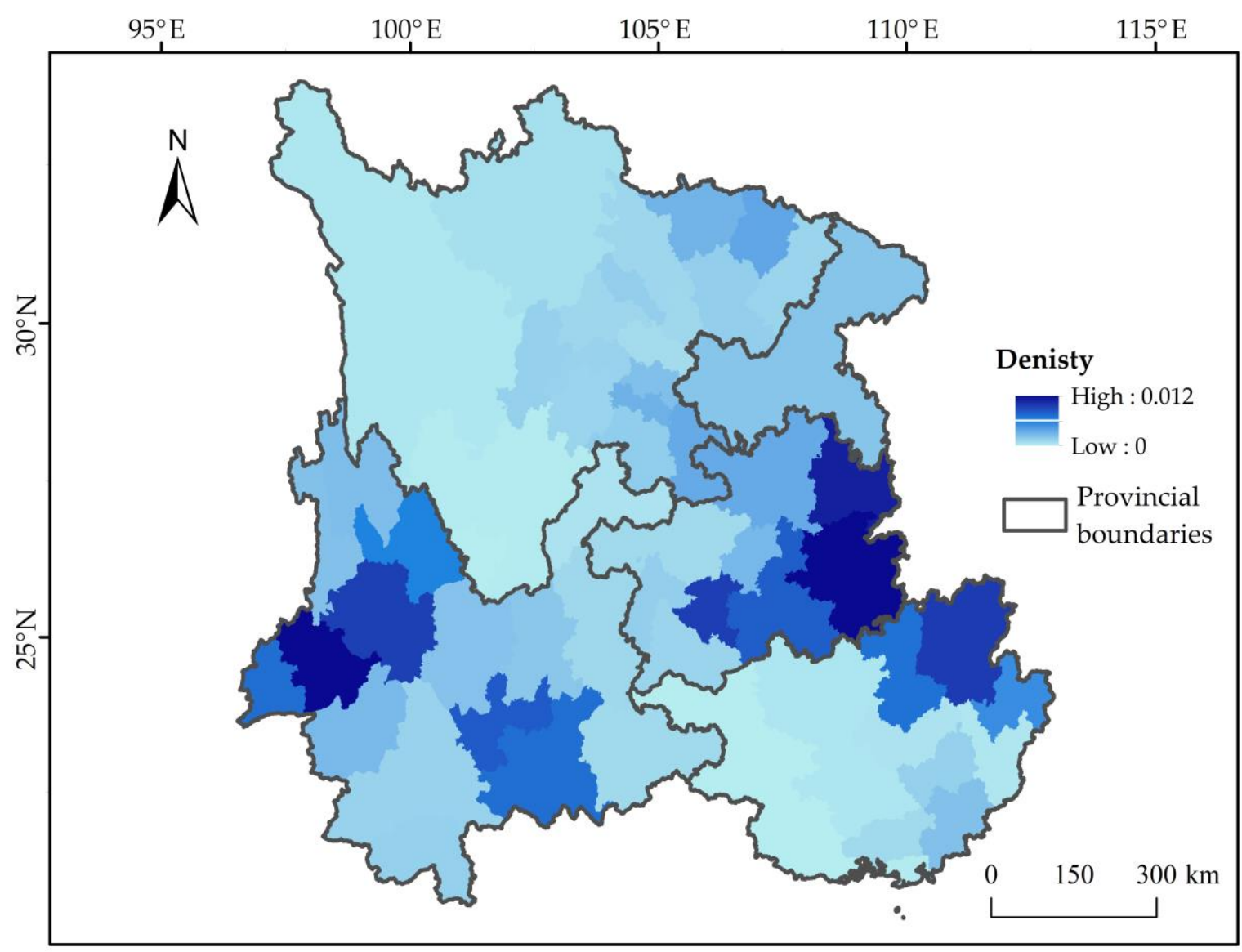

Figure 2. Distribution map of the kernel density of traditional villages in Southwest China.

As shown in Table 3, the elevation distribution range of traditional villages in Southwest China was large, and with the increase in elevation, the number of traditional villages increased first and then decreased. A total of 1867 traditional villages were mainly distributed in areas at an elevation below $2000 \mathrm{~m}$, accounting for $86.6 \%$ of all traditional villages. In areas with an elevation above $3500 \mathrm{~m}$, there were only 27 traditional villages, accounting for $1.25 \%$ of all traditional villages. The traditional villages in Southwest China were mainly distributed on the relatively flat ground or the middle and lower parts of mountains. Among them, there were 1142 traditional villages in less than $20 \%$ of the relative positions, accounting for $53 \%$ of all the traditional villages in Southwest China. Only 128 traditional villages were distributed in areas with a relative position higher than $60 \%$, accounting for $5.9 \%$. The traditional villages in Southwest China were mainly distributed in gentle slope areas suitable for village construction and living, and the distribution of traditional villages decreased considerably with the increase in slope. There were 1759 
traditional villages distributed in areas with a slope less than $15^{\circ}$, accounting for $81.5 \%$; only 95 villages were distributed in relatively steep areas with a slope greater than $25^{\circ}$, accounting for $4.41 \%$. Traditional villages in Southwest China had obvious dependence on water resources. There were 929 traditional villages whose distance to the nearest river was less than $5 \mathrm{~km}$, accounting for $43.1 \%$ of all traditional villages, and 527 traditional villages were within $5-10 \mathrm{~km}$ around the river, accounting for $24.5 \%$. The greater the distance from water, the fewer the traditional villages. It can be seen that, under different geographical conditions, the distribution of traditional villages obviously has a certain preference.

Table 3. Traditional villages in different ranges of geographical characteristics.

\begin{tabular}{|c|c|c|c|c|c|}
\hline Elevation (m) & Number & Percentage & Relative Position (\%) & Number & Percentage \\
\hline$<500$ & 499 & $23.16 \%$ & $<20$ & 1142 & $52.99 \%$ \\
\hline $500 \sim 1000$ & 694 & $32.20 \%$ & $20 \sim 40$ & 555 & $25.75 \%$ \\
\hline $1000 \sim 2000$ & 674 & $31.28 \%$ & $40 \sim 60$ & 330 & $15.31 \%$ \\
\hline $2000 \sim 3500$ & 261 & $12.11 \%$ & $60 \sim 80$ & 116 & $5.38 \%$ \\
\hline$>3500$ & 27 & $1.25 \%$ & $>80$ & 12 & $0.56 \%$ \\
\hline Slope $\left(^{\circ}\right)$ & Number & Percentage & Nearest Water Distance (km) & Number & Percentage \\
\hline$<3$ & 764 & $35.45 \%$ & $<5$ & 929 & $43.10 \%$ \\
\hline $3 \sim 8$ & 516 & $23.94 \%$ & $5 \sim 10$ & 527 & $24.50 \%$ \\
\hline $8 \sim 15$ & 479 & $22.23 \%$ & $10 \sim 15$ & 307 & $14.25 \%$ \\
\hline $15 \sim 25$ & 301 & $13.97 \%$ & $15 \sim 20$ & 187 & $8.68 \%$ \\
\hline$>25$ & 95 & $4.41 \%$ & $>20$ & 205 & $9.50 \%$ \\
\hline
\end{tabular}

\subsection{Cluster Analysis of Traditional Villages in Southwest China}

According to the cluster analysis results, traditional villages in Southwest China were divided into four categories (Figure 3). Villages of cluster A are mainly distributed in western Sichuan, accounting for only $6.54 \%$ of all villages. The average elevation, slope, and traffic costs of these villages are $2816.1 \mathrm{~m}, 18.27^{\circ}$, and 0.31 , respectively, which are significantly higher than those of other villages. In contrast, the population density of cluster A was significantly lower than that of other villages. Villages of cluster B were mainly distributed in Southeast Guizhou, Northwest Guizhou, and Northwest Yunnan, accounting for $52.30 \%$ of all villages. The terrain is relatively gentle compared with cluster A, but the average relative position of cluster B is $32.19 \%$, which is significantly higher than other villages, and most of them are located in the middle of mountains or hills. In addition, the population density and per capita GDP of such villages are higher than those of cluster A. Villages of cluster C are mainly distributed in Southeast Guizhou, which has a flat terrain, but the distance to the nearest river averaged $28.19 \mathrm{~km}$, which is significantly higher than that of other clusters. Villages of cluster D are mainly distributed in Southeast Guangxi and Northwest Yunnan, where the terrain is relatively flat. The distances to the nearest river and traffic cost are $3.75 \mathrm{~km}$ and 0.12 , respectively, which are significantly lower than those of other clusters. In addition, due to the convenience of transportation and access to water resources, the population density and per capita GDP of cluster D were 68,576 people $/ \mathrm{km}^{2}$ and RMB 35,300 yuan, respectively, which are significantly higher than those of other villages (Table 4). It can be seen that the geographical environment and social and economic conditions of villages are different among different clusters. 


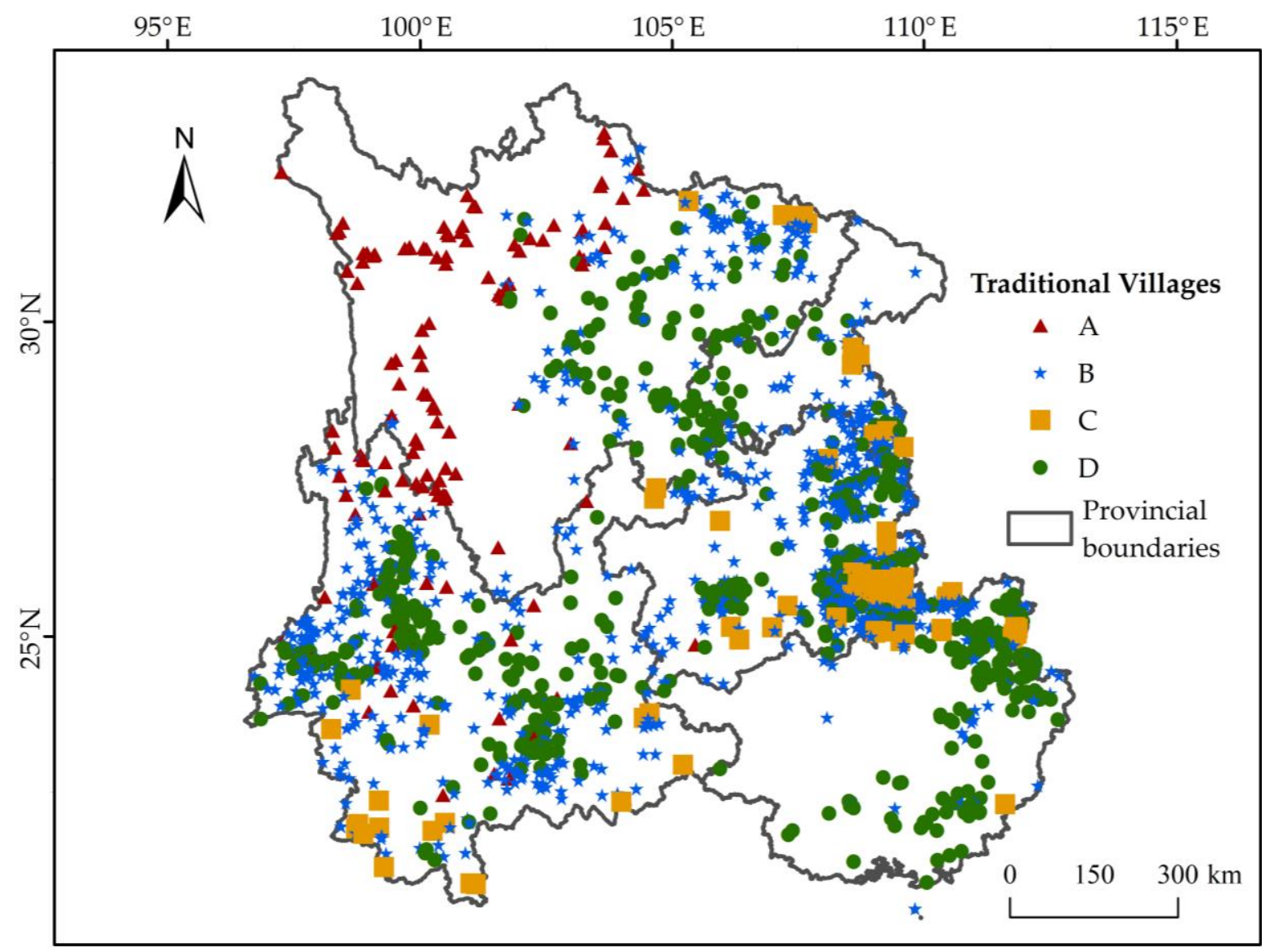

Figure 3. Clustering results of traditional villages.

Table 4. The mean value of the attributes of different clusters.

\begin{tabular}{|c|c|c|c|c|c|}
\hline Cluster & Count & Percentage (\%) & Elevation (m) & Slope $\left(^{\circ}\right)$ & Relative Position (\%) \\
\hline $\mathrm{A}$ & 141 & 6.54 & $2816.11^{a}$ & $18.27^{\mathrm{a}}$ & $22.46^{\mathrm{b}}$ \\
\hline B & 1127 & 52.30 & $1090.74^{b}$ & $10.88^{b}$ & $32.19^{a}$ \\
\hline C & 143 & 6.64 & $655.94^{\mathrm{d}}$ & $4.35^{\mathrm{c}}$ & $17.45^{\mathrm{b}}$ \\
\hline $\mathrm{D}$ & 744 & 34.52 & $960.55^{c}$ & $2.83^{\mathrm{c}}$ & $10.72^{\mathrm{c}}$ \\
\hline All & 2155 & 100 & 1129.83 & 8.15 & 23.17 \\
\hline Cluster & Count & Nearest Water Distance (km) & Traffic Cost & Population $\left(/ \mathrm{km}^{2}\right)$ & Per GDP $\left(\times 10^{4} \mathrm{RMB}\right)$ \\
\hline A & 141 & $7.34^{\mathrm{c}}$ & $0.31^{\mathrm{a}}$ & $109.10^{c}$ & $2.69^{c}$ \\
\hline $\mathrm{B}$ & 1127 & $9.51^{b}$ & $0.19^{c}$ & $174.37^{\mathrm{b}}$ & $3.07^{b}$ \\
\hline $\mathrm{C}$ & 143 & $28.19^{a}$ & $0.22^{b}$ & $209.50^{b}$ & $2.66^{\mathrm{c}}$ \\
\hline $\mathrm{D}$ & 744 & $3.75^{\mathrm{d}}$ & $0.12^{\mathrm{d}}$ & $685.76^{a}$ & $3.53^{\mathrm{a}}$ \\
\hline All & 2155 & 8.62 & 0.18 & 348.98 & 3.17 \\
\hline
\end{tabular}

Note: An independent sample nonparametric test was conducted on the spatial feature attribute values of clustering results. We used ${ }^{a, b, c}$, and ${ }^{\mathrm{d}}$ to indicate the significance between groups and label from large to small.

\subsection{Landscape Pattern around Traditional Villages}

The land around traditional villages in Southwest China was mainly forest, shrub, and cultivated land, but there were differences in landscape composition among the different village clusters (Table 5). Forest, shrub, grassland, and cultivated land were the main land use types around villages of cluster A, especially in the buffer zone with a radius of $1 \mathrm{~km}$; the PLAND and MPS of grassland and bare land were significantly higher than those of other clusters. The land use types of traditional villages of cluster B were mainly forests and cultivated land, accounting for $65 \%$, of which the PLAND and MPS of forests were 
significantly higher than those of the other clusters. The land use type of traditional villages of cluster $\mathrm{C}$ was mainly forests and shrubs. The PLAND and MPS of forests and shrubs were high, especially the MPS of shrubs. The land use types of traditional villages of cluster D were mainly forest and cultivated land, accounting for 65\%. The PLAND and MPS of cultivated land, water, and artificial surfaces were obviously higher than those of the other clusters.

Table 5. The PLAND and MPS of land use types around traditional villages in Southwest China.

\begin{tabular}{|c|c|c|c|c|c|c|c|c|c|c|c|}
\hline \multirow{2}{*}{ Cluster } & \multirow{2}{*}{$\begin{array}{c}\text { Land } \\
\text { Use }\end{array}$} & \multicolumn{5}{|c|}{ PLAND (\%) } & \multicolumn{5}{|c|}{ MPS $\left(\mathbf{k m}^{2}\right)$} \\
\hline & & $1 \mathrm{~km}$ & $2 \mathrm{~km}$ & $3 \mathrm{~km}$ & $5 \mathrm{~km}$ & $10 \mathrm{~km}$ & $1 \mathrm{~km}$ & $2 \mathrm{~km}$ & $3 \mathrm{~km}$ & $5 \mathrm{~km}$ & $10 \mathrm{~km}$ \\
\hline \multirow{7}{*}{ A } & $\mathrm{LU}_{1}$ & 27.70 & 33.92 & 36.84 & 39.32 & 39.98 & 0.29 & 0.61 & 0.84 & 0.85 & 0.81 \\
\hline & $\mathrm{LU}_{2}$ & 22.27 & 23.02 & 22.97 & 23.13 & 22.57 & 0.19 & 0.29 & 0.28 & 0.30 & 0.27 \\
\hline & $\mathrm{LU}_{3}$ & 22.78 & 22.57 & 22.86 & 22.99 & 22.89 & 0.20 & 0.31 & 0.55 & 0.92 & 0.81 \\
\hline & $\mathrm{LU}_{4}$ & 24.83 & 19.46 & 17.21 & 14.98 & 12.83 & 0.24 & 0.38 & 0.34 & 0.49 & 0.27 \\
\hline & $\mathrm{LU}_{5}$ & 1.70 & 1.17 & 0.92 & 0.82 & 0.84 & 0.03 & 0.05 & 0.05 & 0.12 & 0.13 \\
\hline & $\mathrm{LU}_{6}$ & 2.39 & 1.53 & 1.05 & 0.66 & 0.47 & 0.05 & 0.12 & 0.13 & 0.13 & 0.12 \\
\hline & $\mathrm{LU}_{7}$ & 1.24 & 0.97 & 0.81 & 0.91 & 2.07 & 0.02 & 0.02 & 0.02 & 0.04 & 0.12 \\
\hline \multirow{7}{*}{$\mathrm{D}$} & $\mathrm{LU}_{1}$ & 34.30 & 39.31 & 41.80 & 44.64 & 46.72 & 0.47 & 0.93 & 1.14 & 1.16 & 1.05 \\
\hline & $\mathrm{LU}_{2}$ & 17.96 & 19.03 & 19.63 & 19.76 & 19.84 & 0.23 & 0.42 & 0.45 & 0.48 & 0.47 \\
\hline & $\mathrm{LU}_{3}$ & 11.50 & 11.31 & 11.15 & 11.05 & 11.22 & 0.08 & 0.09 & 0.09 & 0.09 & 0.11 \\
\hline & $\mathrm{LU}_{4}$ & 30.25 & 26.05 & 23.76 & 21.56 & 19.68 & 0.33 & 0.42 & 0.46 & 0.47 & 0.38 \\
\hline & $\mathrm{LU}_{5}$ & 1.33 & 1.13 & 1.13 & 1.12 & 1.00 & 0.03 & 0.07 & 0.13 & 0.26 & 0.21 \\
\hline & $\mathrm{LU}_{6}$ & 3.94 & 2.52 & 1.99 & 1.54 & 1.30 & 0.05 & 0.05 & 0.05 & 0.05 & 0.06 \\
\hline & $\mathrm{LU}_{7}$ & 0.65 & 0.73 & 0.71 & 0.69 & 0.74 & 0.01 & 0.02 & 0.02 & 0.03 & 0.04 \\
\hline \multirow{7}{*}{$C$} & $\mathrm{LU}_{1}$ & 31.11 & 36.10 & 39.71 & 43.25 & 46.33 & 0.46 & 1.07 & 1.18 & 1.25 & 1.16 \\
\hline & $\mathrm{LU}_{2}$ & 24.70 & 27.25 & 27.69 & 27.78 & 27.59 & 0.45 & 1.22 & 1.72 & 1.58 & 1.40 \\
\hline & $\mathrm{LU}_{3}$ & 7.99 & 8.07 & 8.14 & 8.08 & 8.42 & 0.05 & 0.07 & 0.08 & 0.08 & 0.08 \\
\hline & $\mathrm{LU}_{4}$ & 27.54 & 21.22 & 18.28 & 15.69 & 14.50 & 0.33 & 0.41 & 0.38 & 0.31 & 0.23 \\
\hline & $\mathrm{LU}_{5}$ & 1.03 & 0.82 & 0.78 & 0.64 & 0.62 & 0.02 & 0.04 & 0.07 & 0.12 & 0.14 \\
\hline & $\mathrm{LU}_{6}$ & 4.07 & 2.36 & 1.77 & 1.29 & 1.01 & 0.05 & 0.05 & 0.05 & 0.05 & 0.06 \\
\hline & $\mathrm{LU}_{7}$ & 0.72 & 0.44 & 0.47 & 0.57 & 0.62 & 0.01 & 0.01 & 0.02 & 0.05 & 0.05 \\
\hline \multirow{7}{*}{$\mathrm{D}$} & $\mathrm{LU}_{1}$ & 24.68 & 30.00 & 32.82 & 36.41 & 41.17 & 0.28 & 0.55 & 0.73 & 0.89 & 0.97 \\
\hline & $\mathrm{LU}_{2}$ & 14.22 & 15.43 & 16.18 & 16.90 & 17.30 & 0.18 & 0.32 & 0.36 & 0.35 & 0.35 \\
\hline & $\mathrm{LU}_{3}$ & 9.16 & 9.47 & 9.55 & 9.30 & 8.94 & 0.05 & 0.07 & 0.07 & 0.07 & 0.07 \\
\hline & $\mathrm{LU}_{4}$ & 40.15 & 36.33 & 33.86 & 30.67 & 26.73 & 0.56 & 0.96 & 1.07 & 0.86 & 0.67 \\
\hline & $\mathrm{LU}_{5}$ & 2.65 & 2.36 & 2.18 & 1.98 & 1.67 & 0.06 & 0.12 & 0.17 & 0.24 & 0.25 \\
\hline & $\mathrm{LU}_{6}$ & 8.32 & 5.62 & 4.41 & 3.41 & 2.56 & 0.10 & 0.10 & 0.09 & 0.08 & 0.08 \\
\hline & $\mathrm{LU}_{7}$ & 0.58 & 0.57 & 0.53 & 0.49 & 0.52 & 0.01 & 0.01 & 0.02 & 0.02 & 0.03 \\
\hline
\end{tabular}

Note: $\mathrm{LU}_{1}, \mathrm{LU}_{2}, \mathrm{LU}_{3}, \mathrm{LU}_{4}, \mathrm{LU}_{5}, \mathrm{LU}_{6}$, and $\mathrm{LU}_{7}$ refer to forest, shrub, grassland, cultivated land, water, artificial surface, and bare land, respectively.

The changes in the different land use types around traditional villages along with the buffer radius were basically the same. With an increase in the radius, the proportion of the forest area increased, while the proportions of cultivated land and artificial surface area decreased. However, the proportions of shrub and bare land remained basically stable. The MPS of forest, cultivated land, and shrub increased first and then decreased with increasing buffer radius.

With the increase in the buffer radius, the changes in PD and SHDI of the different traditional villages at the landscape level are presented in Figure 4. With the increase in buffer radius, the PD of traditional villages in Southwest China gradually decreased, while SHDI showed an increasing trend. There were some differences in the landscape pattern index of the land use of the four village clusters. When the buffer radius increased from 1 to $5 \mathrm{~km}$, the SHDI of cluster A changed smoothly, whereas it increased considerably when the buffer radius increased to $10 \mathrm{~km}$. The mean PD and SHDI values of cluster $C$ in each buffer zone were lower than those of the other villages. The PD mean values of cluster A, $\mathrm{B}$, and $\mathrm{D}$ and the SHDI mean values of clusters $\mathrm{B}$ and $\mathrm{D}$ in each buffer zone were similar 
to those of all villages. In comparison, the PD and SHDI of all landscapes in Southwest China were 0.77 and 1.59, respectively. The PD of traditional villages in the different buffer radii were higher than those of all landscapes in Southwest China, while SHDI values were lower than those of all landscapes in Southwest China.
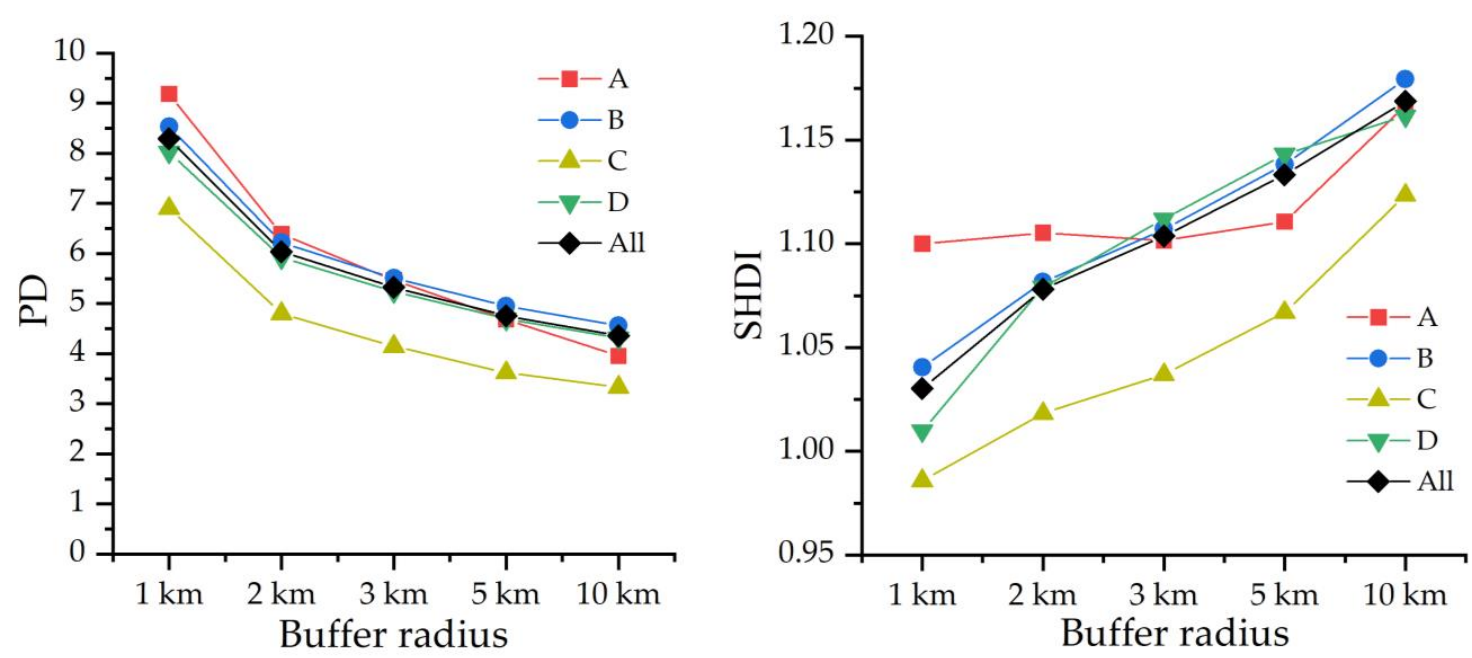

Figure 4. The changes in PD and SHDI of different village clusters with buffer radius.

\section{Discussion}

\subsection{Factors Driving the Spatial Distribution of Traditional Villages}

An advantageous natural environment can provide abundant natural resources, suitable living conditions, and convenient transportation, which are important for regional development [51]. Traditional villages in Southwest China are distributed in aggregation, with obvious regional differences. High-density aggregation areas formed in Southeast Guizhou, Northeast Guangxi, and Central and Northwest Yunnan, closely related to the geographical characteristics, hydrological conditions, and economic development level. In Southwest China, the elevation differs widely and the terrain is complex and diverse. To facilitate production and living activities of villagers including the construction of facilities, farming, and alleviating the shortage of resources, traffic congestion and other problems, traditional villages are mostly distributed in areas with low elevations and gentle slopes. Water resources is an important factor for the production and life of traditional villages. Rich water resources increase the natural resources around the villages [52]. To better allocate and use water resources, traditional villages in Southwest China are more located in areas closer to the river. At present, some traditional villages in Southwest China are still located in places with a relatively poor natural environment. For example, some traditional villages in the Western Sichuan have special buildings, living habits, and production methods that are different from those in plain areas, so as to adapt to some uninhabitable geographical environments. However, the populations are relatively sparse and are only capable of maintaining themselves, which seriously restricts the regional social and economic development.

\subsection{Land Use around Traditional Villages under Different Distribution Characteristics}

Forests, cultivated land, and shrubs were the dominant land use around traditional villages in Southwest China, but there were obvious differences in land use types in different types of traditional villages due to the influence of geographical environment and hydrological conditions. For example, the traditional villages in cluster A were located on the Western Sichuan with relatively uniform distribution of cultivated land, forests, shrubs, and grasslands. However, due to the flat terrain and abundant resources, traditional villages in cluster D had large-scale cultivated land areas. 
Su's study showed that human activities interfere with the natural environment, resulting in increased fragmentation and decreased landscape pattern diversity [53]. In Southwest China, the landscape fragmentation of the traditional village significantly decreased with the increase in the buffer radius. The main reason was that the landscape type was mainly the cultivated land for production activities in the areas close to the traditional villages $[21,54]$. Thus, the intensity of human activities was high, which had a significant impact on the ecological environment. With increasing radius in the buffer analysis, the proportion of cultivated land area decreased and the forest increased, the natural environment was relatively stable in relatively flat areas, the intensity of human activities decreased, and the fragmentation of the landscape decreased.

\subsection{Protection and Sustainable Development of Traditional Villages}

Traditional villages not only preserve history but also advance with the development of human civilization [1]. The landscape pattern around traditional villages is a stable landscape pattern formed by the interaction between the village and nature over a long period, and improper construction of traditional villages might damage the villages and the natural landscape $[55,56]$. With the development of ecological civilization construction and rural revitalization, the protection of traditional villages should pay full attention to the all-round protection of their traditional culture, ecological environment, and social economy, implementing precise protection measures for traditional villages of different regions, types, and characteristics.

The villages of cluster $\mathrm{A}$, located in remote and high mountains with a relatively harsh living environment, are facing a higher risk of abandonment in the context of rapid urbanization. Therefore, it might be necessary to focus on planning their livelihood, developing the economy reasonably, providing more policy support, and reducing additional disturbances to the surrounding environment. The villages of cluster $B$ are located in mountainous areas, but mostly around cities, so they are suitable for the development of tourism by taking advantage of the convenient transportation and through active publicity. Cluster $C$ has relatively limited water resources, so it is necessary to improve the supply of water resources and develop suitable production modes to improve the economic level in the process of protection and development. Cluster D has favorable conditions and convenient transportation, but excessive interference of human activities should be avoided. Obviously, the government plays an important role in promoting the sustainable development of rural areas [57].

\section{Conclusions}

Traditional villages in Southwest China are clustered, with obvious regional differences. High-density aggregations are mainly distributed in Southeast Guizhou, Northeast Guangxi, and Central and Northwest Yunnan, where relatively low elevation, gentle slope, relatively low position, convenient transportation, and nearby water sources can provide a guarantee for the production and living activities of the residents.

Traditional villages in Southwest China were divided into four clusters according to the geographical environment, hydrological conditions, and traffic conditions. The landscape composition around traditional villages was found to be mainly forest, shrub, and cultivated land, but there were obvious differences in land-use types in different types of traditional villages. Moreover, the landscape fragmentation of the traditional village significantly decreased with the increase in the buffer radius. Our research proposed different protection measures for traditional villages in different regions, types, and characteristics, which can provide theoretical support and policy reference for the protection and sustainable development of traditional villages.

Our research still had some possible limitations. The traditional villages in this study were simplified to spatial point elements, so the spatial layout of each village may not be reflected; and this research did not take into account the cultural and historical factors of traditional villages, which may lead to deviations in results of the study. Future research 
can combine the internal structure of traditional villages and their culture and history to further explore the development process and continuity of traditional villages.

Author Contributions: Conceptualization, X.Z. and H.D.; formal analysis, X.Z.; funding acquisition, H.D.; investigation, X.Z. and J.W.; methodology, X.Z. and H.D.; project administration, H.D.; supervision, H.D.; visualization, X.Z.; writing—original draft, X.Z.; writing—review \& editing, X.Z., J.W. and H.D. All authors have read and agreed to the published version of the manuscript.

Funding: This research was funded by the National Key Research and Development Program of China (No. 2016YFC0502106).

Conflicts of Interest: The authors declare no conflict of interest.

\section{References}

1. Feng, J. The Dilemma and Development Path of Traditional Villages: Traditional Villages are Another Type of Cultural Heritage. Folk Cult. Forum 2013, 7-12. [CrossRef]

2. Guidelines on Strengthening the Protection and Development of Traditional Villages. Available online: http://www.mohurd.gov. cn/wjfb/201212/t20121219_212337.html (accessed on 15 April 2021).

3. Liu, Y.; Yang, R.; Li, Y. Potential of Land Consolidation of Hollowed Villages under Different Urbanization Scenarios in China. J. Geogr. Sci. 2013, 23, 503-512. [CrossRef]

4. Wang, M.; Webber, M.; Finlayson, B.; Barnett, J. Rural Industries and Water Pollution in China. J. Environ. Manag. 2008, 86, 648-659. [CrossRef] [PubMed]

5. Liu, Y. Introduction to Land Use and Rural Sustainability in China. Land Use Policy 2018, 74, 1-4. [CrossRef]

6. China National Bureau of Statistics. Available online: http:/ / www.stats.gov.cn/ (accessed on 15 April 2021).

7. Liu, Y.; Li, Y. Revitalize the World's Countryside. Nature 2017, 548, 275-277. [CrossRef]

8. Wang, H.; Chiou, S. Research on the Sustainable Development of Traditional Dwellings. Sustainability 2019, 11, 5333. [CrossRef]

9. Tao, W.; Chen, H.; Lin, J. Spatial Form and Spatial Cognition of Traditional Village in Syntactical View: A Case Study of Xiaozhou Village, Guangzhou. Acta Geogr. Sin. 2013, 68, 209-218. [CrossRef]

10. Bański, J.; Wesołowska, M. Transformations in Housing Construction in Rural Areas of Poland's Lublin Region-Influence on the Spatial Settlement Structure and Landscape Aesthetics. Landsc. Urban Plan. 2010, 94, 116-126. [CrossRef]

11. Fu, J.; Zhou, J.; Deng, Y. Heritage Values of Ancient Vernacular Residences in Traditional Villages in Western Hunan, China: Spatial Patterns and Influencing Factors. Build. Environ. 2021, 188, 107473. [CrossRef]

12. Xu, X.; Liu, J.; Xu, N.; Wang, W.; Yang, H. Quantitative Study on the Evolution Trend and Driving Factors of Typical Rural Spatial Morphology in Southern Jiangsu Province, China. Sustainability 2018, 10, 2392. [CrossRef]

13. Lu, L.; Ling, S.; Jiao, H.; Wang, L. Landscape Features and Mechanism of Huizhou Ancient Village. Sci. Geogr. Sin. 2004, 24, 660-665. [CrossRef]

14. Kang, J.; Zhang, J.; Hu, H.; Zhou, J.; Xiong, J. Analysis on the Spatial Distribution Characteristics of Chinese Traditional Villages. Prog. Geogr. 2016, 35, 839-850. [CrossRef]

15. Xiong, M. Spatial Distribution and Influencing Factors of Traditional Villages in China. J. Beijing Inst. Technol. 2014, 16, 153-158. [CrossRef]

16. Jin, J.; Yan, H. Analyzing the Causes of Spatial Differentiation of the Traditional Villages in Gansu Province, Western China. J. Geosci. Environ. Prot. 2020, 8, 12-25. [CrossRef]

17. Fang, Y.; Liu, J. Cultural Landscape Evolution of Traditional Agricultural Villages in North China-Case of Qianzhai Village in Shandong Province. Chin. Geogr. Sci. 2008, 18, 308-315. [CrossRef]

18. Wang, L.; Wen, C. Traditional Villages in Forest Areas: Exploring the Spatiotemporal Dynamics of Land Use and Landscape Patterns in Enshi Prefecture, China. Forests 2021, 12, 65. [CrossRef]

19. Nowak, A.; Grunewald, K. Landscape Sustainability in Terms of Landscape Services in Rural Areas: Exemplified With A Case Study Area in Poland. Ecol. Indic. 2018, 94, 12-22. [CrossRef]

20. Statuto, D.; Cillis, G.; Picuno, P. Analysis of the Effects of Agricultural Land Use Change on Rural Environment and Landscape through Historical Cartography and GIS Tools. J. Agric. Eng. 2016, 47, 28. [CrossRef]

21. Ma, B.; Tian, G.; Kong, L.; Liu, X. How China's Linked Urban-rural Construction Land Policy Impacts Rural Landscape Patterns: A Simulation Study in Tianjin, China. Landsc. Ecol. 2018, 33, 1417-1434. [CrossRef]

22. Chen, Z.; Liu, Y.; Feng, W.; Li, Y.; Li, L. Study on Spatial Tropism Distribution of Rural Settlements in the Loess Hilly and Gully Region based on Natural Factors and Traffic Accessibility. J. Rural Stud. 2019. [CrossRef]

23. Pickett, S.T.A.; Cadenasso, M.L. Landscape Ecology: Spatial Heterogeneity in Ecological Systems. Science 1995, 269, 331-334. [CrossRef] [PubMed]

24. Liang, X.; Li, Y. Identification of Spatial Coupling between Cultivated Land Functional Transformation and Settlements in Three Gorges Reservoir Area, China. Habitat Int. 2020, 104, 102236. [CrossRef]

25. Ministry of Housing and Urban-Rural Development of the People's Republic of China. Available online: http:/ /www.mohurd. gov.cn/ (accessed on 15 April 2021). 
26. Yang, R.; Xu, Q.; Long, H. Spatial Distribution Characteristics and Optimized Reconstruction Analysis of China's Rural Settlements during the Process of Rapid Urbanization. J. Rural Stud. 2016, 47, 413-424. [CrossRef]

27. Elbakidze, M.; Angelstam, P. Implementing Sustainable Forest Management in Ukraine's Carpathian Mountains: The Role of Traditional Village Systems. For. Ecol. Manag. 2007, 249, 28-38. [CrossRef]

28. Shen, Y.; Li, T.; Tang, M.; Deng, H. Spatial Patterns of Biocultural Diversity in Southwest China. Acta Ecol. Sin. 2019, 39, $2454-2461$. [CrossRef]

29. Shen, Y.; Mao, S.; Qiu, S.T.; Deng, H. Spatiotemporal Pattern of Cultural Diversity in Southwest China. Acta Ecol. Sin. 2018, 38, 7596-7606. [CrossRef]

30. List of the First Batch of Chinese Traditional Villages. Available online: http://www.mohurd.gov.cn/wjfb/201212/t20121219_21 2340.html (accessed on 10 May 2021).

31. List of the Second Batch of Chinese Traditional Villages. Available online: http://www.mohurd.gov.cn/wjfb/201308/t20130830_ 214900.html (accessed on 10 May 2021).

32. List of the Third Batch of Chinese Traditional Villages. Available online: http://www.mohurd.gov.cn/wjfb/201412/t20141203_21 9694.html (accessed on 10 May 2021).

33. List of the Fourth Batch of Chinese Traditional Villages. Available online: http://www.mohurd.gov.cn/wjfb/201612/t20161222 230060.html (accessed on 10 May 2021).

34. List of the Fifth Batch of Chinese Traditional Villages. Available online: http:/ /www.mohurd.gov.cn/wjfb/201906/t20190620_24 0922.html (accessed on 10 May 2021).

35. Baidu Map Coordinate Picking System. Available online: https://api.map.baidu.com/lbsapi/getpoint/index.html (accessed on 10 May 2021).

36. Remote Sensing and Digital Earth, Chinese Academy of Sciences. Available online: http:/ / eds.ceode.ac.cn/sjglb/dataservice.html (accessed on 10 May 2021).

37. Remote Sensing Monitoring Data of China's Land Use in 2018. Available online: https: / www.resdc.cn/data.aspx?DATAID=264 (accessed on 10 May 2021).

38. Urban Data Party. Available online: https:/ / www.udparty.com/index.php/lists/data?page=0\&bk_id=279 (accessed on 10 May 2021).

39. Chongqing Bureau of Statistics. Chongqing Statistical Yearbook 2016; China Statistics Press: Beijing, China, 2016; ISBN 978-7-50377846-9.

40. Guangxi Bureau of Statistics. Guangxi Statistical Yearbook 2016; China Statistics Press: Beijing, China, 2016; ISBN 978-7-5037-7895-7.

41. Guizhou Bureau of Statistics. Guizhou Statistical Yearbook 2016; China Statistics Press: Beijing, China, 2016; ISBN 978-7-5037-7896-4.

42. Sichuan Bureau of Statistics. Sichuan Statistical Yearbook 2016; China Statistics Press: Beijing, China, 2016; ISBN 978-7-5037-7871-1.

43. Yunnan Bureau of Statistics. Yunnan Statistical Yearbook 2016; China Statistics Press: Beijing, China, 2016; ISBN 978-7-5037-7903-9.

44. Wang, Y.; He, H. Spatial Data Analysis Method, 1st ed.; Science Press: Beijing, China, 2007; ISBN 978-7-03-018966-0.

45. King, T.L.; Bentley, R.J.; Thornton, L.E.; Kavanagh, A.M. Using Kernel Density Estimation to Understand the Influence of Neighbourhood Destinations on BMI. BMJ Open 2016, 6, e008878. [CrossRef]

46. Li, T.; Qiu, S.; Mao, S.; Bao, R.; Deng, H. Evaluating Water Resource Accessibility in Southwest China. Water 2019, 11, 1708. [CrossRef]

47. Li, F.; Ye, Y.; Song, B.; Wang, R. Evaluation of Urban Suitable Ecological Land Based on the Minimum Cumulative Resistance Model: A Case Study from Changzhou, China. Ecol. Model. 2015, 318, 194-203. [CrossRef]

48. Tang, L.; Ruth, M.; He, Q.; Mirzaee, S. Comprehensive evaluation of trends in human settlements quality changes and spatial differentiation characteristics of 35 Chinese major cities. Habitat Int. 2017, 70, 81-90. [CrossRef]

49. Yang, Z. Region Spatial Cluster Algorithm Based on Ward Method. China Popul. Resour. Environ. 2010, 20, 382-386.

50. Xu, S.; Li, S.; Zhong, J.; Li, C. Spatial Scale Effects of the Variable Relationships between Landscape Pattern and Water Quality: Example from an Agricultural Karst River Basin, Southwestern China. Agric. Ecosyst. Environ. 2020, 300, 106999. [CrossRef]

51. Jiang, G.; Zhang, F.; Chen, J.; Duan, Z.; Su, Z. Analysis of the Driving Forces of Change of Rural Residential Areas in Beijing Mountainous Areas Based on Logistic Regression Model. Trans. Chin. Soc. Agric. Eng. 2007, 23, 81-87. [CrossRef]

52. Guo, X.; Ma, L.; Zhang, Q. A GIS-based Research on the Spatial Evolution Characteristics and Driving Mechanism of the Rural Settlements in Qin'an County. Econ. Geogr. 2012, 32, 56-62. [CrossRef]

53. Su, S.; Xiao, R.; Jiang, Z.; Zhang, Y. Characterizing Landscape Pattern and Ecosystem Service Value Changes for Urbanization Impacts at an Eco-regional Scale. Appl. Geogr. 2012, 34, 295-305. [CrossRef]

54. Long, H.; Li, T. The Coupling Characteristics and Mechanism of Farmland and Rural Housing Land Transition in China. J. Geogr. Sci. 2012, 22, 548-562. [CrossRef]

55. YulitrisnaDewi, L.K. Modeling the Relationships between Tourism Sustainable Factor in the Traditional Village of Pancasari. Procedia Soc. Behav. Sci. 2014, 135, 57-63. [CrossRef]

56. Lim, J.C.; Choi, B.K.; Kim, S.Y.; Eom, B.C.; Kim, J.W. Korean Traditional Village Forest (Ma-Eul-Soop) and Potential Natural Vegetation: A Case Study on the Sachon-Ri Garo-Soop in Gyeongsangbuk-do, South Korea. J. Plant Biol. 2016, 59, 515-524. [CrossRef]

57. Marsden, T.; Sonnino, R. Rural development and the regional state: Denying multifunctional agriculture in the UK. J. Rural Stud. 2008, 24, 422-431. [CrossRef] 